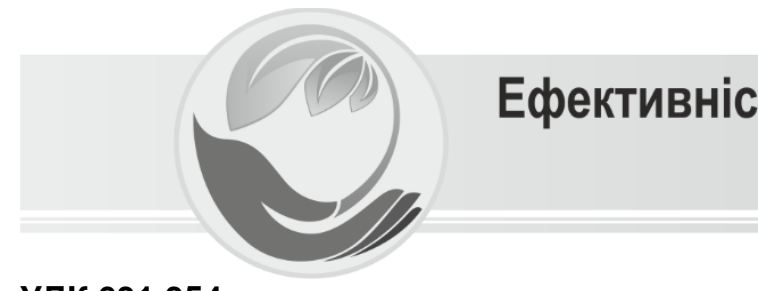

УдК 631.354 https://doi.org/10.37700/enm.2020.4(18).73 - 77

\title{
Обгрунтування механізованого процесу збирання насіння соняшників
}

\author{
В.М. Мартишко \\ Національний університет біоресурсів і природокористування України, \\ (м. Київ, Україна) email:vm.mart@ukr.net
}

\begin{abstract}
Наведено результати теоретичних досліджень процесу збирання соняшнику із застосуванням пристроїв зернозбирального комбайна, визначено допустиму швидкість комбайна при умові мінімального осипання насіння, доведено ефективність використання збирально - транспортних загонів.
\end{abstract}

Ключові слова: насіння соняшнику, зернозбиральний комбайн, жатка, пристосування для збирання соняшників, швидкість руху, втрати насіння.

Постановка проблеми. Головна вимога до збирання врожаю соняшнику - забезпечення мінімальних втрат насіння і створення належних умов для вирощування наступних культур.

Важливим фрактором збереження врожаю, $€$ правильні терміни початку збору врожаю. Як дуже раннє, так і занадто пізнє збирання в результаті впливають на істотні втрати.

Основним критерієм початку збору врожаю $€$ вологість насіння, яка залежить від фази дозрівання і погодних умов. Наливання насіння соняшнику закінчується через 34-40 діб після завершення масового цвітіння посіву, коли рослина має вологість близько 25-30\%.

Основним технічним засобом на збиранні насіння соняшників в господарствах України залишається зернозбиральний комбайн. Збирання насіння соняшників комбайнами із зерновими жатками призводить до значних втрат цінного насіння через відсутність пристосувань, що спонукає до створення пристосування до комбайна існуючих комбайнів при відсутності спеціальних соняшникових жаток. Потреба в пристосуванні для збирання соняшнику обумовлена і тим, що останніми роками спостерігається тенденція в збільшенні площ під посівами соняшнику, тому виникає потреба в розвитку технічних засобів для збирання насіння соняшників.

На ряду з конструктивними удосконаленнями $€$ потреба в розробці рекомендацій з технологічної наладки зернозбиральних комбайнів, особливо вибору швидкості руху комбайна, з метою скорочення втрат насіння при збиранні.
Аналіз останніх досліджень і публікацій. Оптимальні строки збору врожаю наступають коли 20-25\% всього посіву має жовтий і жовтобуре забарвлення, а інші рослини сухі і бурого кольору. На цьому етапі ступінь вологості знижується до 11-13\%, кошиків - до 69-75\%, стебел до $60-70 \%$ [4].

Визначається зрілість соняшнику за кольором кошики. Розрізняють 3 ступеня зрілості: - жовта, при якій листя і зворотна сторона кошика, мають лимонно-жовтий колір. Кошик має вологість межах 85-88\%, вологість насіння - 30-40\%;

- бура. Кошик має темно-бурий колір. Вологість кошики становить 39,5-50\%, насіння - 10-12\%; - повна. Всихання рослини. Вологість кошики $19-20 \%$, насіння-7-10\% [1].

Для прискореного достигання насіння, скорочення термінів збирання врожаю, одержання сухого насіння, а також для зменшення втрат від застосовують хімічні препарати, тобто десиканти.

При вирощуванні соняшнику важливе місце займає збирання врожаю, що визначає рівень втрат насіння. Аналіз результатів досліджень процесу збирання свідчить, що джерелом найбільших втрат насіння соняшнику є жатка зернозбирального комбайна.

Збирання соняшнику зернозбиральним комбайном із серійною зерновою жаткою з ексцентриковим мотовилом призводить до втрат насіння в межах 15-20\%. Тому задля зменшення втрат використовують спеціальні пристрої.

Роботи з удосконалення засобів механізації, які б покращували якості показники роботи машин на збиранні насіння соняшнику в останні роки практично не ведуться. 
Аналіз результатів пошукових досліджень показує, що при збиранні соняшників найбільші втрати насіння спостерігаються за жниваркою зернозбирального комбайна від осипання насіння. При входженні планки мотовила в рослинну масу внаслідок удару відбувається вибивання насіння 3 кошиків, втрати насіння можуть сягати до 5-6 ц/га. При збиранні соняшників зернозбиральним комбайном із серійною жниваркою з ексцентриковим мотовилом спостерігається перевалювання зрізаних кошиків через планку мотовила та опадання їх на поле.

Пристрої жаток для збирання насіння соняшників, обладнані підіймачами стебел, дають змогу значно зменшити втрати насіння при збиранні урожаю в порівнянні 3 пристроями типу ПЗС-8[6]. При цьому важливо забезпечити таку швидкість комбайна, коли осипання насіння від дії робочих органів жатки, буде мінімальним.

Мета досліджень - зменшення втрат насіння соняшників за рахунок вибору допустимої швидкості комбайна в процесі збирання.

Виклад основного матеріалу. При обґрунтуванні максимальної швидкості комбайна приймаємо наступне припущення:

- рух агрегату рівномірний і прямолінійний;

- маса комбайна буде рівна $M$;

- а маса стебла рівна $\mathrm{m}$.

Приймаємо до уваги той факт, що ударна дія буде відбуватися носком підіймача стебла або брусом різального апарату об стебла соняшника.

Нехай маса $M$ (комбайн), який рухається із швидкістю $V_{0}$, зустрічається з масою $m$ (стебла), швидкість якої рівна 0.

В результаті поштовху маса $M$ змінить свою швидкість до значення $V$, а маса $m$ набуде швидкість $V$. Величина поштовху або імпульсу рівна.

$$
P \Delta t=M\left(V_{0}-V\right)=m V,
$$

де $P$ - сила удару, $\mathrm{H} ; \Delta t$ - проміжок часу дії сили, с.

Під час руху комбайна підіймач стебла вдаряє по стеблу соняшника і відхиляє його від вертикалі (Рис.1.). В такому випадку на підіймач стебла діє сила пружності стебла і сила інерції маси стебла. Згідно теорії удару, при ударі по тілу достатньої довжини із швидкістю $V$ частинки стебла коливаються з кутовою швидкістю $\omega$. За час удару, коли поперечний згин стебла досягає величини $f_{1}$, поперечна деформація поширюється на довжину $l_{1}$.

Так як на стебло підіймача стебла діє з силою

$$
P=\gamma F V c,
$$

де $F$ - площа поперечного перерізу стебла, м²; $\gamma$ - щільність стебла, кг/м; $V$ - швидкість комбайна, м/с; $c$ - швидкість поширення деформації в стеблі, м/с.
Запишемо

$$
V=\frac{2 \pi}{T} f_{1}=\omega f_{1},
$$

де $\omega$ - кутова швидкість, рад./с; $f_{1}$ - поперечний згин стебла, м; $l_{1}$ - довжина поширення поперечної деформації, м.

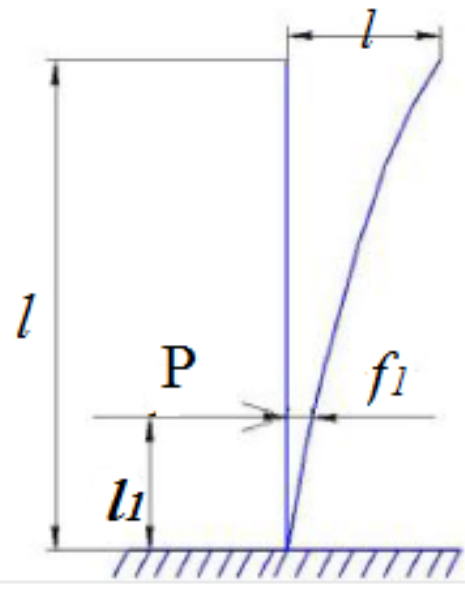

Рис. 1. Схема дії підіймача на стебло соняшника: $l$ - довжина стебла; $l_{1}$ - довжина на яку діє поперечна деформація; $P$ - сила удару підіймача по стеблу; $f$ - поперечним згин стебла; $f_{1}-$ максимальний поперечний згин стебла

Як наслідок, знайдемо добуток

$$
V_{c}=\omega^{2} f_{1} l_{1} \text {. }
$$

Відповідно до робіт В.П. Горячкіна, сила $P$ надається тільки четверті маси стебла, тоді

$$
\frac{m}{4}=\gamma F l_{1} \text {. }
$$

Визначаємо силу удару на підіймач стебла

$$
P=\gamma F V=(\gamma F c) V c .
$$

Множник являє собою масу,що сприймає удар в одиницю часу, $V$ - швидкість удару, м/с.

Прирівнявши попередні вирази отримаємо рівняння:

$$
\frac{F G f_{1}}{l_{1}}=\gamma F \omega^{2} f_{1}
$$

де $G$ - модуль зсуву, Па;

Знайдемо кутову $\omega$ швидкість:

$$
\omega=\frac{1}{l_{1}} \sqrt{\frac{G}{\gamma}} .
$$

Тоді швидкість комбайна з урахування межі напружень можна визначити 


$$
V=\frac{P}{F \gamma c}
$$

або

$$
V=\frac{f_{1}}{l_{1}} \sqrt{\frac{G}{\gamma}}=\frac{p}{G} \sqrt{\frac{G}{\gamma}}=p \sqrt{\frac{1}{G \gamma}},
$$

Отже максимальна швидкість агрегату має бути меншою

$$
V_{\max }<p \sqrt{\frac{1}{G \gamma}}
$$

Якщо

$$
\gamma=\frac{\delta}{g}
$$

В такому випадку

$$
V_{\max }<p \sqrt{\frac{g}{G \gamma}}
$$

де $\delta$ - питома вага стебла, $\mathrm{H} ; g$ - прискорення вільного падіння, м/с².

Результати розрахунків показують, що швидкість комбайна при збиранні соняшників не повинна перевищувати 4м/с, або 14 км/год.

Для ефективного використання технічного потенціалу машин доцільно створити збирально - транспортний загін у складі таких ланок: підготовки полів до збирання; комбайно - транспортної; технічного обслуговування та усунення несправностей машин; післязбиральної обробки насіння [3].

Провідною є комбайно - транспортна ланка, а провідним агрегатом - комбайновий.

Розрахунок комбайно - транспортної ланки виконується в такій послідовності.

Робочу швидкість руху комбайна, при якій буде забезпечено його оптимальну пропускну здатність, знайдемо за формулою:

$$
V_{p}=\frac{3,6 \cdot g_{\text {опт }}}{B_{\mathrm{p}} \cdot И_{\mathrm{H}}\left(1+\mathrm{K}_{\mathrm{c}}\right)}, \text { км/год, }
$$

де $g_{\text {опт }}$ - оптимальна пропускна здатність молотарки, кг/с; $B_{\mathrm{p}}$ - робоча ширина захвату приставки, м; И, - урожайність насіння, т/га; К явність кошиків і стебел у збираній масі.

Продуктивність зернозбирального комбайна за годину змінного часу дорівнює:

$$
W_{г}=\frac{3,6 g_{\text {отп }}}{h_{\mathrm{H}}\left(1+\mathrm{K}_{\mathrm{c}}\right)} \cdot \tau, \text { га/год }
$$

де $\tau$ - коефіцієнт використання часу зміни,

$$
\tau=0,60-0,75 \text {. }
$$

Менші значення $\tau$ рекомендується приймати для вітчизняних комбайнів, які поки що недостатньо надійні, та при роботі на полях з короткими гонами з складною конфігурацією.

Затрати робочого часу (праці):

$$
\mathrm{H}=\frac{n}{W_{\Gamma}}, \text { год/га, }
$$

де $n$ - кількість механізаторів, що працюють одночасно, чол.

Витрату палива на одиницю роботи визначаємо за такою формулою:

$$
Q=\frac{N_{\text {ен }} \cdot g_{\mathrm{e}} \cdot K_{3}}{W_{\Gamma}}, \text { кг/га, }
$$

де $N_{\text {ен }}$ - номінальна потужність двигуна комбайна, кВт; $g_{\mathrm{e}}$ - питома витрата палива, кг/кВт.год; для двигунів типу СМД $g_{\mathrm{e}}=0,24-0,25$ кг/кВт · год, а для двигунів іноземних фрірм $g_{\mathrm{e}}=0,18-0,20$ кг $/$ кВт $\cdot$ год; $K_{3}-$ коефіцієнт завантаження двигуна; орієнтовно рекомендується прийняти $K_{3}=0,70-0,85$ (більші значення будуть при роботі з подрібнювачем).

Приведені затрати на зернозбиральний комбайн дорівнюють:

$$
\Pi_{3}=\mathrm{C}+\xi \cdot \mathrm{K}, \text { грн } / г \mathrm{a},
$$

де C - прямі експлуатаційні затрати, грн/га; $\xi$ нормативний коефіцієнт ефективності капітальних вкладень, $\xi=0,15 ; К$ - величина капітальних вкладень, грн/га.

Прямі експлуатаційні затрати на одиницю роботи визначаємо за формулою:

$$
\mathrm{C}=\mathrm{C}_{1}+\mathrm{C}_{2}+\mathrm{C}_{3}+\mathrm{C}_{4} \text {, грн } / \text { га, }
$$

де $\mathrm{C}_{1}$ - оплата праці персоналу, який працює на комбайні, грн/га; $\mathrm{C}_{2}$ - вартість витрачених паливо мастильних матеріалів, грн/га; $\mathrm{C}_{3}$ - відрахування на амортизацію комбайна, грн/га; $\mathrm{C}_{4}$ - відрахування на технічне обслуговування комбайна, грн/га.

Оплата праці обслуговуючого персоналу дорівнює:

$$
\mathrm{C}_{1}=\frac{\mathrm{n}_{5} \mathrm{~T}_{5}+n_{6} \mathrm{~T}_{6}}{W_{\text {зм}}}, \text { грн } / г \mathrm{a},
$$

де $n_{5}$ i $n_{6}-$ кількість механізаторів, які працюють на комбайні за кожною кваліфрікацією (розрядом); $\mathrm{T}_{5}$ і $\mathrm{T}_{6}$ - оплата праці за змінну норму виробітку працівника кожної кваліфрікації (п'ятого і шостого розряду), грн .

За умови роботи лише комбайнера у формулі (17) маємо: $\mathrm{n}_{5} \mathrm{~T}_{5}=0$.

Вартість паливно - мастильних матеріалів:

$$
\mathrm{C}_{2}=\bigsqcup_{\kappa} Q \text {, грн } / г \mathrm{a},
$$

де $Ц_{\kappa}$ - комплексна ціна 1 кг палива, грн.

Відрахування на амортизацію зернозбирального комбайна дорівнює: 


$$
\mathrm{C}_{3}=\frac{\mathrm{Б}_{\mathrm{\kappa}} \alpha_{\mathrm{\kappa}}}{100 W_{\mathrm{\Gamma}} t_{\mathrm{\kappa}}}, \text { грн } / \text { га, }
$$

де $5_{к}$ - балансова вартість комбайна, грн; $\alpha_{\text {к }}$ - норма відрахувань на амортизацію, $\alpha_{\text {к }}=15 \% ; t_{\text {к }}-$ річне завантаження комбайна, год.

Відрахування на технічне обслуговування:

$$
\mathrm{C}_{4}=\frac{\mathrm{Б}_{\mathrm{K}} \alpha_{\mathrm{T}}}{100 W_{\mathrm{r}} t_{\mathrm{K}}}, \text { грн } / \text { га, }
$$

де $\alpha_{\text {т }}$ - норма відрахувань на технічне обслуговування, $\alpha_{\text {т }}=6,5 \%$;

Величина капітальних вкладень дорівнює:

$$
\kappa=\frac{Б_{\kappa}}{W_{г} t_{\kappa}}, г р н / г а,
$$

Структурний склад комбайно - транспортної ланки включає зернозбиральні комбайни та автомобілі для відвезення насіння з поля на тік. Необхідну кількість зернозбиральних комбайнів для виконання заданого обсягу робіт у встановлені строки знаходимо за фрормулою:

$$
n_{\mathrm{\kappa}}=\frac{U}{W_{\Gamma} T_{\text {зм }} n_{\text {дн }}},
$$

де $U$ - площа збираного соняшника, га; $T_{3 м}-$ три-

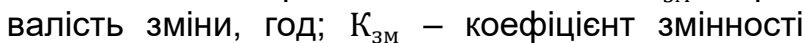
(приймається в залежності від наявності комбайнерів у господарстві); $n_{\text {дн }}$ - тривалість збиральних робіт, днів.

При розрахунках приймаємо $n_{\text {дн }}=6-8$.

Необхідну кількість автомобілів для відвезення насіння від групи зернозбиральних комбайнів визначаємо за формулою:

$$
n_{\mathrm{a}}=\frac{n_{\mathrm{\kappa}} t_{\mathrm{a}}}{\left(t_{б}+t_{\mathrm{p} . \text { б. }}\right) n_{\sigma}},
$$

де $t_{\mathrm{a}}$ - час циклу (рейсу) автомобіля, хв; $t_{\text {б }}, t_{\mathrm{p.б.}}-$ час відповідно заповнення бункера комбайна насінням і його розвантаження, хв; $n_{\text {б }}$ - кількість бункерів насіння, яка вміщується в кузові автомобіля.

Тривалість рейсу автомобіля визначаємо за формулою, хв:

$$
t_{\mathrm{a}}=\left(t_{\text {р.б. }}+t_{\text {пер }}\right) \cdot n_{\text {б }}+\frac{120 S}{V_{\mathrm{a}}}+t_{\text {зв }}+t_{\text {розв }}
$$

де $t_{\text {пер }}$ - час переїзду автомобіля від краю поля до комбайна або від одного комбайна до іншого, хв; $S$ - відстань перевезення насіння на тік, км; $V_{\mathrm{a}}$ - середньотехнічна швидкість руху автомобіля, км/год; $t_{\text {зв }}$ і $t_{\text {розв }}-$ тривалість зважування і розвантаження насіння, хв.

За даними хронометражних спостережень можна прийняти $t_{\text {р.б. }}=t_{\text {розв }}=5 \mathrm{xB} ; t_{3 в}=2 \mathrm{xв}$. Ceредньотехнічна швидкість руху автомобіля в польових умовах знаходиться в межах $23-27$ км/год.

Час заповнення бункера комбайна насінням дорівнює:

$$
t_{\text {б }}=\frac{S_{\text {б }} \cdot 60}{V_{\mathrm{p}} \cdot 1000}=0,06 \frac{S_{\text {б }}}{V_{\mathrm{p}}}, \mathrm{xB},
$$

де $S_{б}$ - шлях заповнення бункера, м.

$$
S_{\text {б }}=\frac{10^{4} V_{\text {б }} \gamma_{3} \varphi}{\mathrm{B}_{\mathrm{p}} h_{3}}, \mathrm{M},
$$

де $V_{6}-$ місткість бункера, м $^{3} ; \gamma_{3}$ - насипна маса насіння, т/м ${ }^{3}$. Для насіння соняшника $\gamma_{3}=0,42-$ 0,$45 ; \varphi$ - коефіцієнт заповнення-спорожнення бункера комбайна; $\varphi=0,90-0,95$.

Після підстановки розрахункових значень у фрормулу (23) знайдемо необхідну кількість автомобілів.

Висновки. Результати теоретичних досліджень процесу збирання насіння соняшників свідчать про ефективність удосконалення пристосувань до зернозбиральних комбайнів а також обґрунтування технологічних параметрів їх використання, зокрема допустима швидкість руху комбайна не повинна перевищувати 14 км/год.

\section{Література:}

1. Базалій В.В., Добровольський А.В. Наукові можливості підвищення ефективності виробництва продукції соняшника. Таврійський науковий вісник, 2015. №93. С. $3-6$

2. Гаврилюк М.М., Салатенко В.Н., Чехов А.В. Олійні культури в Україні - навч. посібник [за редакцією Салатенка В.Н..]. К.: Основа, 2008. 420 с. 37

3. Гречкосій В., Щука В. Комплексна механізація вирощування та збирання соняшнику / Ж. „, Агробізнес сьогодні ", 2011, №6. - С. 45 - 48.

4. Мельник І., Гречкосій В., Марченко В. Комплексна механізація виробництва соняшнику / Ж. „Пропозиція”, 2004, №11. - С. 40-41.

5. Троценко В.І. Соняшник: селекція, насінництво, технологія вирощування: Монографія / В.І.Троценко. - Суми: Унів. книга, 2001. - 184c.

6. Жатки для уборки подсолнечника серии Falcon [Електронний ресурс]/ Ростсельмаш: - 19292016. - Режим доступу: https://rostselmash.com/ products/adapters/zhatki-falcon/

7. Бердянский завод сельхозтехники [Електронний ресурс]: - 2016. - Режим доступу: http://bzst.com.ua/

\section{References:}

1. Bazalii, V. V. and Dobrovolskyi, A. V. (2015) 'Naukovi mozhlyvosti pidvyshchennia efektyvnosti vyrobnytstva produktsii soniashnyka', Tavriiskyi naukovyi visnyk, (93), pp. 3-6. 
2. Havryliuk, M. M., Salatenko, V. N. and Chekhov, A. V. (2008) Oliini kultury v Ukraini - navch. posibnyk. Edited by V. N. Salatenko. Kyiv: Osnova.

3. Hrechkosii, V. and Shchuka, V. (2011) 'Kompleksna mekhanizatsiia vyroshchuvannia ta zbyrannia soniashnyku', Ahrobiznes sohodni, (6), pp. 45-48.

4. Melnyk, I., Hrechkosii, V. and Marchenko, V. (2004) 'Kompleksna mekhanizatsiia vyrobnytstva soniashnyku', Propozytsiia, (11), pp. 40-41.
5. Trotsenko, V.I. (2001) Soniashnyk: selektsiia, nasinnytstvo, tekhnolohiia vyroshchuvannia: Monohrafiia. Sumy: Univ. knyha.

6. ZHatki dlya uborki podsolnechnika serii Falcon (2020) Rostsel'mash: - 1929-2016. Available at: URL: $\quad$ https://rostselmash.com/products/adapters/zhatki-falcon/

7. Berdianskyi zavod selkhoztekhnyky (2016). Available at: http://bzst.com.ua/.

\section{Аннотация}

\section{Обоснование механизированного процесса сбора семян подсолнечника}

\section{В.М. Мартишко}

Приведены результаты теоретических исследований процесса уборки подсолнуха с применением устройств зерноуборочного комбайна, определена допустимая скорость комбайна при условии минимального осыпания семян, доказана ефективность использования уборочно-транспортных отрядов.

Ключевые слова: семена подсолнечника, зерноуборочный комбайн, жатка, приспособление для уборки подсолнечника, скорость движения, потери семян.

\section{Abstract \\ Substantiation of the mechanized process of harvesting sunflower seeds}

\section{V.M. Martyshko}

Privedeny rezul'taty teoreticheskikh issledovaniy protsessa sbora podsolnukha s primeneniyem ustroystv zernouborochnogo kombayna, opredelenno dopustimuyu skorost' kombayna iz usloviy minimal'nogo osypaniyu semyan.

Keywords: sunflower seeds, combine harvester, reaper, sunflower harvesting equipment, speed, seed loss.

Бібліографічне посилання/ Bibliography citation: Harvard

Martyshko, V.M. (2020). Substantiation of the mechanized process of harvesting sunflower seeds. Engineering of nature management, (4(18), pp. $73-77$.

Подано до редакції / Received: 22.10.2020 